Vol. $7, n^{\circ} 2 \mid 2003$

Varia

\title{
The Lords of Discipline. The Penal Colony Guards of New Caledonia and Guyana
}

Stephen A. Toth

\section{(2) OpenEdition \\ Journals}

Electronic version

URL: https://journals.openedition.org/chs/544

DOI: $10.4000 /$ chs. 544

ISSN: 1663-4837

Publisher

Librairie Droz

Printed version

Date of publication: 1 December 2003

Number of pages: $41-60$

ISBN: 2-600-008990-3

ISSN: $1422-0857$

\section{Electronic reference}

Stephen A. Toth, "The Lords of Discipline. The Penal Colony Guards of New Caledonia and Guyana", Crime, Histoire \& Sociétés / Crime, History \& Societies [Online], Vol. 7, n² | 2003, Online since 25 February 2009, connection on 22 March 2022. URL: http://journals.openedition.org/chs/544 ; DOI: https:// doi.org/10.4000/chs.544

This text was automatically generated on 22 March 2022.

(c) Droz 


\title{
The Lords of Discipline. The Penal Colony Guards of New Caledonia and Guyana
}

\author{
Stephen A. Toth
}

\section{AUTHOR'S NOTE}

I am grateful to the anonymous referees of Crime, History \& Societies for their comments. I would also like to thank the staff of the Centre des Archives d'Outre-Mer, Aix-enProvence for their assistance in the location of materials for this article. Unless otherwise indicated, all translations are my own.

\section{Introduction}

1 By the mid nineteenth century the banishment of citizens overseas had long been a policy of penal administration in France. Indeed, during the Revolution and the Directorate, political dissidents were deported to the territorial holdings of Louisiana and Algeria, and deportation for political offenses was made an official part of the Napoleonic Code of 1810. These individuals were not subject to any institutionalized form of punishment, however, but were simply required to live in a designated area for a specified length of time (most were later pardoned and repatriated) ${ }^{2}$.

2 In 1854 legislation was passed that formally established the South American territory of Guyana as a destination for common-law criminals convicted of felonies (expanded in 1864 to include the South Pacific island of New Caledonia, amid reports of high death tolls from malaria and yellow fever) ${ }^{3}$. This law specified that convicts sentenced to hard labor no longer be sent to the port cities of Brest, Rochefort, and Toulon -where they had worked in the dockyards since the decommission of the government's Mediterranean galley fleet in $1748^{4}$-but instead serve their sentences in Guyana where 
they would be engaged in the «most painful work of colonization».Those sentenced to eight years or more of imprisonment would remain permanently in the colony, while shorter-term convicts would serve an additional term equal to the length of their sentences. This provision, known as doublage, rested on the assumption that the freed convict would remain in the colony and live as a libéré (a free colonist), thereby contributing to the development of the French empire ${ }^{5}$.

Unlike the Benthamite panopticon ${ }^{6}$ in which adherence to the regimented and nearly monastic existence of the cell was intended to be conducive to reflection, remorse, and repentance, prisoners in the penal colonies were housed in communal barracks, and shackled together by ball and chain. While corporal punishment was not a part of the penitential regime, guards in the penal colonies routinely engaged in the beating and torture of the bagnards, and even carried out public executions for those guilty of legal and disciplinary infractions while in their charge. Indeed, given their remote location and great distance from the metropole, local administrators and guards had immediate and total control over life. Yet, as the linchpin and ultimate moralizing agent of the bagnes, the story of the penal colony guard has yet to be told.

Was he an automaton, a lowly instrument of state-sanctioned dominance and control? As Holocaust survivor and author Primo Levi observed, even SS guards whose «daily ration of slaughter was studded with arbitrary and capricious acts were not monoliths $»^{7}$. Utilizing daily reports, internal memoranda, and correspondence between local administrators and the Ministry of the Marine, this article follows Levi's lead in that it attempts to understand -while neither absolving nor condoning -behavior by examining the institutional life and culture of the guards.

5 The bagnes were without question places of unparalleled misery for those prisoners unfortunate enough to be held within their confines, as numerous histories of the institution attest ${ }^{8}$. Yet what has emerged from this historiography is an institution that is unchanging, undifferentiated, and ahistorical. We are privy to the penal colonies only in relation to their symbolic importance or in terms of their inherent cruelty and barbarism.

6 There is evidence, however, that the penal colonies are being examined in new ways. Anthropologist Peter Redfield has juxtaposed the bagnes with the Ariane space program in an effort to explain Guyana's uniqueness; both in terms of its nature and culture, and in terms of its complex place in French memory and contemporary consciousness ${ }^{9}$. Guyana was an epistemological and geographic site which allowed for the experimentation and dissemination of French knowledge and power. Yet in this vein the bagne is only one part of a much larger story surrounding the intersection of technology and colonial development in the nineteenth and twentieth centuries.

7 For historian Alice Bullard, the raison d'être of the penal colony in New Caledonia was the inculcation of a French national identity among the exiled Communards and the Kanaks (the indigenous people of the island) ${ }^{10}$. Through their control of the bagne, and by extension daily life in the colony, officials «civilized» by using the «body»-both metaphorically and corporeally -as a site of discursive and violent intervention. With the Communards and the Kanaks as the primary focus, however, little attention is paid to the common-law convict who comprised the vast majority of the population of New Caledonia in the late nineteenth and early twentieth centuries.

8 The specter of Michel Foucault hovers above these, and most other works that touch upon issues of deviance and social control. Through his genealogical delineation of the 
normalizing techniques that emerged in conjunction with the factory, army, and school, Foucault also uncovered the various strains of a nineteenth-century discourse that cohered into a mechanism of imprisonment -that is, the penitentiary-conceived not simply to punish but to reform criminals. Thus, the body was the focus for a new kind of power relation in which capital and corporal punishment gave way to the meticulous observation, investigation, and control of the human subject, as normalization proceeded from the strict separation, organization, and perpetual visibility of the prisoner ${ }^{11}$.

Although Foucault's analysis enlightens it also elides, as he conflates rhetoric with administrative practice. By exaggerating the influence of juridical and social-scientific authorities, Foucault indulges in his own fantasy about the power of intellectual discourse itself. Indeed, as historian Peter Zinoman has recently discovered in his study of the prisons in French Indochina, these institutions were not sites of methodical bureaucratic control, but pre-modern jails that had the unintended effect of imbuing in its prisoners -through their shared sense of suffering at the hands of an «antiquated and ill-disciplined $»^{12}$ penal regime -a distinct national identity which actually helped to facilitate and strengthen anti-French sentiments. Thus, the penal colonies were not like Foucault's caricature of the modern prison; a vast, gray, monolithic institution, mechanically ordered and rigidly stratified through the ever-invasive panoptic gaze of professionals and staff.

10 This leaves to historians the task of tracing how the various strategies of normative reason embedded within such institutions were actually implemented and diffused. What we will uncover in the case of the guards is that despite rhetoric that emphasized militarism, and a professional structure designed to fashion and instill a sense of pride and purpose, they, like the prisoners, were beyond the pale; a group somehow rejected by their peers. Even with the establishment of a complex set of procedures, guidelines, and a system of appointments, perquisites, and promotions, the corps never took on the air of a professional military service as a variety of obstacles -structural and individual-impeded its development as an effective disciplinary apparatus of the bagnes.

\section{The Early Days}

11 Those guards who disembarked from the first prison transport ships onto Guyanese soil in 1854 and New Caledonia in 1864, came under withering criticism from local administrators displeased with their comportment. One penal colony inspector in New Caledonia complained of «wardens who display a lack of energy, bad conduct, and a nearly continual drunkenness that makes them the object of contempt and scorn among most transportés». He maintained that such misconduct was pervasive and evidence of a «malaise that makes most wardens no better than those whom they guard $»^{13}$. Another such report noted that of those guards not returned to France for «their deplorable attitude and misconduct, most are debauched drunks who have succumbed to every vice imaginable, and are at this very moment a risk to security» ${ }^{14}$.

12 Statistics compiled by the penal administration seemed to support this general charge of misbehavior among the guards. Indeed, of the 561 individuals admitted to the penal colony corps in both Guyana and New Caledonia between 1854-1867, nearly one- 
quarter, or 127 men, were returned to France for dereliction of duty, usually drunkenness ${ }^{15}$.

Those who evinced what Governor Guillain of New Caledonia termed a «moral gangrene $»^{16}$ were, unlike their local superiors, former non-commissioned officers in the army and navy. Penal colony officials were critical of this pattern of recruitment, however, for they believed that time spent «in civilian life after their departure from the service appears to have led to a weakening of the military esprit de corps and tradition that is so important for the maintenance of order in such rigorous and isolated surroundings $»^{17}$.

14 Another concern for the administration was the fact that these individuals had been culled from the staffs of the disreputable shipyard bagnes. Such prior employment was perceived not as invaluable preparation for service in the penal colonies, but rather an experience that «more or less taints one by the practices that operated there» ${ }^{18}$. Indeed, corruption was rife in the shipyard bagnes, and guards routinely engaged in black marketing, theft, and the procurement of homosexual unions.

While such accusations were neither new nor solely limited to the bagnes of Toulon, Brest, and Rochefort-complaints of illicit activities among guards extended to the maisons centrales and departmental prisons as well -the unsavory reputation of men who had worked in the dockyards preceded their arrival in the penal colonies. So, it is not altogether surprising that they received little respect from their counterparts in active military service. Indeed, the frequent complaints of guards «who are constantly excluded from the dining table of the ship's officers while access is given to officials of the Church», led the Governor of Guyana to ask naval authorities to «inform these officers that their behavior vis-a-vis surveillants is disrespectful», and that they should «allow the wardens to join them for repasts» during their overseas voyage ${ }^{19}$. In relating the case of a warden who complained that a soldier refused to acknowledge his greeting, the governor of Guyana informed the Ministry that such «incidents are ever more common as the antagonism between the wardens and soldiers of other corps have become worse and worse, and even violent. The wardens have become increasingly sensitive to such displays of disrespect $\aleph^{20}$. Indeed, as name calling and brawling were not at all uncommon during the first years of penal colony settlement in Guyana, guards frequently ran afoul of local gendarmes as well.

officials were also convinced that the poor attitude and performance of their charges was the result of a malfunctioning career structure. Although guards were divided into three classes and pay scales and were to respect the authority of those adjudants and sous-adjudants in charge, there was no established hierarchy other than seniority based on years of experience, and thus no opportunity for meritorious advancement within the corps itself. In what was a leitmotiv during the early years of the bagnes, a commission established by the Ministry in 1856 to investigate the failure to attract and retain guards in Guyana concluded that «it is important for the maintenance of order that the administration recognize the rude conditions these men face while serving in this most difficult and important task... and therefore endeavor to create a superiority of functions and the possibility of advancement based upon distinguished service and remarkable aptitude, so that the corps attracts elite subjects with legitimate ambitions in an honorable career ${ }^{21}$.

17 Such considerations were usually formulated within the framework of a direct comparison to the military. With the expansion of the army during the Second Empire, 
prospects for advancement improved for noncommissioned army officers, but remained unchanged for Guyana's wardens. By the outbreak of the Franco-Prussian War, nearly one million troops were either in active service, in the reserve, or in the Garde Nationale Mobile ${ }^{22}$. The successive wars in the Crimea and Italy, as well as colonial campaigns in Indochina, China, Syria, Senegal, and Mexico, all demanded creation of new posts for commissioned and noncommissioned officers, especially for those with field promotions. This expansion probably made the prospect-however slight it might have actually been -of social advancement through a career in the military more appealing to many non-commissioned officers who might have otherwise considered serving in the penal colony corps.

There were other impediments to recruitment for service in the penal colonies as well. Concomitant with Napoleon III's coup d'État and subsequent policy of political repression-particularly in the provinces, where counterrevolutionary activity was quite high -was an extension of the gendarmerie in France, which diminished the number of non-commissioned officers available to recruit. As of 1853, according to historian Howard Payne, «461 new brigades were in uniform, bringing the gendarmerie's complement to four thousand men over that of 1847. About twenty-four thousand gendarmes now patrolled France» ${ }^{23}$. The number of municipal police also more than doubled from 5,000 to 12,150 men during the Second Empire ${ }^{24}$.

With the expansion of the army and gendarmerie, and given Guyana's insalubrious reputation-well deserved, for 168 guards had died from yellow fever between $1854-1867^{25}$-recruitment to the corps was «nearly nonexistent because the obligation to serve continually in Guyana has discouraged men from joining». Administrators complained «that surveillance has become nearly impossible in our establishments... as the number of wardens continues to decrease to levels below that permitted by the department» ${ }^{26}$. In 1861 there were 115 wardens for the 1,248 prisoners in Guyana -or approximately one guard for every eleven condamnés -well below the one-to-four ratio prescribed in the legislation that first established the penal colony in 1854. Even in the healthier climes of New Caledonia, there were only 98 wardens for 1,100 prisoners in $1867^{27}$. As a result, officials in both colonies were forced to draw upon civil gendarmes to bolster security.

\section{Militarization}

With the rapid turnover and indiscipline within the ranks, penal colony officials recognized that «the service of transportation, always executed in the open air, in which the warden is in constant contact with the condamné chain gangs, has nothing in common with the work of the prison guard, whose contact with the prisoner is contained within the walls of the prison ${ }^{28}$. This realization implied that the penal colony service had «a special need for men trained to obey and command, and who have not lost all the qualities of a good non-commissioned officer» ${ }^{29}$. After years of relative inaction the Ministry also came to this conclusion and determined that it was necessary to «replace the standing guard with a corps organized and animated by a zealousness of service similar to that which operates in a very special army corps» ${ }^{30}$.

21 Making a call to regiments of the army and navy in November 1867, the Ministry invited all noncommissioned officers still in active military service to join the penal colony corps. Candidates had to be between the ages of twenty-five and forty, and 
literate. In this regard, a cursory examination -covering grammar and orthography, rudimentary arithmetic, regulations relative to the regime of transportation, and general principles of penitentiary jurisprudence -was given to all those interested in becoming a penal colony guard. After passing this examination, the NCO signed a contract with the penitentiary administration that obliged him to serve four years in the penal colonies.

In carrying out his assigned tasks, the penal colony guard was to adhere to a strict, military code of conduct. His character was «to be one of exact discipline; wardens are to obey their superiors in totality and are to act on the basis of one single sentiment: duty». He was to exude authority by virtue of his carriage and dress, his bearing toward others within the hierarchy of the corps, and, in his attitude and demeanor toward the transporté. Attitude and bearing was seen as essential «in the battle against the bad instincts of those in his charge», as he was to «always maintain a strict discipline while assuring that the transporté does not escape and meets his obligation to work» ${ }^{31}$. Adorned in military garb - cap, top coat, vest, and lapels carrying grade insignias guards were to be distinguished by ranks structured comparably to the army.

At the top of the hierarchy was the principal warden, who in most cases was a former artillery guard, followed by chief wardens first and second class, who were usually sergeant-majors, and finally wardens first and second class, who were previously sergeants. The lowest rank, warden third class, was roughly equivalent to that of corporal. Behavior signifying the men's place in the hierarchy was minutely detailed: «Each guard should salute with the right hand. If the warden is seated he should always get up and salute when his superior comes into view. The superior should then return the salute. Superiors are to address their inferiors by rank. The inferior is to address the superior by 'mon,' and then the grade of the officer. All guards are to speak to civil functionaries, without qualification, as «sir ${ }^{32}$.

To guarantee that suitable subjects joined the newly formed penal colony corps, military superiors were to vouch for the good character of those interested in guard duty by signing a certificate that verified past good conduct and health. Candidates were approved by the Ministry upon the recommendation of the colonial governor and local commandant. To ensure a prospect for advancement in the corps, the Ministry stipulated that all those serving one year in an inferior grade or class were eligible for promotion, upon the recommendation of a superior and conferral by the governor and the Ministry.

In addition, the 1867 decree stated that all guards were subject to a uniform gradation of punishment for acts of insubordination or indiscipline. A first infraction would result in a verbal reprimand from a superior. A second offense would lead to «an inscription in one's dossier». A third incident would bring about a demotion in class or a prolongation at the lowest rank before possible advancement. A fourth offense would be seen as sufficient grounds for dismissal from the corps. The recalcitrant guard would be returned to the army or navy, where he would finish his tour of duty ${ }^{33}$.

The decree also provided for a substantial increase in salary. The annual remuneration for the newly created position of warden principal was set at 3,700-4,000 francs, more than triple what the most experienced warden earned prior to 1867. The base pay for warden chiefs ranged from 3,000-3,500 francs, and the two highest classes of wardens earned between 2,000-2,500 francs per year. The salary for those first entering the corps nearly quadrupled, from 415 francs to 1,600 francs annually ${ }^{34}$. This compared 
favorably to salaries in the metropole, where earnings for an ordinary guard in a metropolitan prison were typically around 800 francs per year, and a gardien-chef 1,600 to 1,800 francs ${ }^{35}$.

In this context the guard was now a member of a distinct occupational group organized after the military's structure. An attempt to systematize the corps in order to improve its operation and function, the aforementioned measures were also designed to act on another level; the emphasis on discipline and decorum would imbue the guard with such virtues. The reconfigured guard would now be an obedient and reliable instrument of order in the bagnes.

\section{The Reconfigured Guard}

Ministerial and local inspection reports indicate a high level of satisfaction with both the new recruits and those of the old corps who remained. One inspector remarked in 1875 that «military discipline has, little by little, forged the corps of wardens into a cohesive, homogenous force... The governors, inspectors general, and directors of the penitentiary service have succeeded in developing and maintaining a military esprit de corps among the wardens. This has become an elite corps, which today renders a great service» ${ }^{36}$. Governor Guillain of New Caledonia similarly noted that «there has been a great improvement from the first days of transportation. The military corps of surveillants is now generally well recruited. The corps is well composed. They now comprise some capable and meritorious subjects, who have a great interest in advancing in class whenever it is possible» ${ }^{37}$. In a report to the Ministry his successor, Governor de la Richerie, also remarked that «the wardens are by all accounts excellent... [T]hey operate with the best intent and are viewed by the general population as not only guards in the bagne, but as an elite corps of non-commissioned officers $»^{38}$.

The efficacy of the reform measures also seemed evident in the behavior of the prisoners themselves. Governor Guillain remarked that «discipline is very good... Punishment for misbehavior among the transportés is rare, for the condamné now has a great respect for the warden $»^{39}$. A ministerial official was also impressed by «how a perfect propriety is rigorously enforced by the guards... Discipline leaves nothing to be desired. There are few attempts at escape, and those are rarely if ever successful. The corps is now composed of military men who merit every confidence» ${ }^{40}$. One local warden concluded that «the salutary influence of the new corps shows itself every day and in every circumstance among the transportés... Experience demonstrates in an irrefutable manner that the military organization has given the wardens the moral influence necessary to conduct and lead themselves and the transportés» ${ }^{41}$.

\section{The Scandal}

It was not until the publication of newspaper reports in Le Petit National, Réveil Social, Le Citoyen, and Le Temps, however, that a heretofore blithe French reading public was allowed inside the bagne for the first time. What they discovered was «true history in all its details, true-life accounts of suffering», by recently repatriated Communards ${ }^{42}$ 
who recounted «frequent whippings and the regular use of thumb screws» in New Caledonia. One such article summarized life in the bagne in the following manner:

If a guard finds your work unsatisfactory, you receive blows from the whip. If you march too quickly or too slowly, you receive blows from the whip. If you reply or attempt to deny any observation, you receive blows from the whip. For taking a piece of fruit along your daily route to work you receive blows from the whip. For no apparent reason, other than the enjoyment of the guards, you receive blows from the whip ${ }^{43}$.

With growing public outrage, and strident demands for an outside investigation coming from these newspapers ${ }^{44}$, parliament convened a commission to look into the matter in January 1880.

As Bullard has pointed out, corporal punishments such as whippings were allowed by law, but the use of thumbscrews by guards - forbidden by regulation - was an open secret ${ }^{45}$. What remains unexamined, however, is how the aftermath of the Communard scandal shaped the penal colony guard until the closure of the bagnes at the conclusion of the Second World War. Indeed, the revelations of abuse prompted a fundamental reassessment - at least among Ministerial officials - of the militarism embodied in the 1867 decree. Indeed, one detects a move away from discipline and punishment as the modus operandi of the guard, toward a new emphasis on correctional and «rehabilitative» treatment. The penal colony guard was no longer to be bent on obtaining submission and obedience from his prisoners at any cost, but instead to see his task «... as one of regeneration, moral reform, and rehabilitation... At all times one must guard, guide, and supervise. It is necessary that a warden encourage the transporté to work through discernment and tact, rather than threat of punishment» ${ }^{46}$.

In this context, flogging and physical punishment in the bagnes was banned, and in their place a plethora of non-corporal punishments for recalcitrant bagnards were instituted. These included a reduction in the daily ration of wine or tafia for infractions such as laziness or rudeness toward a warden; cellular confinement at night for insubordination or drunkenness, for periods up to one month; cellular confinement day and night, for periods up to one month, for "grave acts of immorality» which included violence toward another bagnard or insulting a guard; and finally, the dungeon (solitary confinement in double chains both day and night) for escape attempts or acts of violence against guards for periods up to two months. For repeat offenses, successive sentences to hard labor were given to condamnés ${ }^{47}$.

This reorientation was not accepted without complaint by local administrators who complained that under the new rules, sanctions could not be imposed unilaterally by guards. Instead, they were handed down by a disciplinary commission composed of the commandant of the camp and two functionaries in the employ of the penitentiary administration and designated by the director of the penitentiary administration. Penal administrators also chafed at the requirement that guards charged with abuse or using their firearms against prisoners be tried before a council of war (a tribunal comprised of various individuals from the Ministry and local colonial officials). The Director of the Penitentiary Administration in Guyana complained of the inconvenience surrounding a «two-month» long trial that depleted the corps of a guard who was rarely replaced by another ${ }^{48}$.

35 If the guard in question was married, a prolonged hearing caused significant hardship for his family, as only the husband could collect the ration upon which the modestly 
paid penal employee depended. Thus, in the man's absence, the wife was forced into debt in order to buy food. "Without the ration", the director remarked, «life is miserable». Nor were the circumstances improved if the family accompanied the guard to the trial's venue as the state provided no expenses for a family's displacement. This prospect of debt was seen by the director as a "powerful motive that hinders the guard in the accomplishment of his work $»^{49}$.

To many it appeared as though the guard was no longer the pillar on which the disciplinary edifice of the bagnes rested. In a book entitled La colonisation et le bagne, one former colonial official, using a pseudonym, asked: «And what of those charged with guarding these shameless mobs who are encouraged by these short-sighted regulations? What do we tell them? These are the men who are obliged to plead extenuating circumstances before tribunals when they are forced to defend themselves ${ }^{50}$ ! In this same vein, an official complained about the low morale of guards and argued that this was the result of the new disciplinary regime «in which guards are subjected from morning until night to insults which cannot be dealt with by precise discipline because of an insufficient punishment... It is much easier to be a guard in a maison centrale in France than in New Caledonia» ${ }^{51}$.

Unlike the metropolitan penitentiary in which discipline had shifted from the body to the soul of the prisoner, there were many in the metropole who believed the need to moralize not only justified, but necessitated, the continued use of violence in the penal colonies. From his vantage point in Paris, attorney A. Rivière charged that with: «the suppression of corporal punishment... the penal colony administration has not had at its disposal an effective and intimidating means of coercion» ${ }^{52}$. Émile Laurent, an early twentieth-century professor of law in Lyon, would complain that «while prisoners who attempted to escape were given twenty-five blows with the whip on the backside by the commandant of the penitentiary, and in the presence of all the transportés... with the suppression of corporal punishment wardens lost the most persuasive means of coercion available to them $»^{53}$.

\section{Daily Life}

In contrast to local officials, however, the Ministry was firmly convinced that what lied at the root of the problem was low pay, inadequate housing, alcoholism, and a stagnant career structure. Indeed, there was a growing realization that life was difficult in the penal colonies, and that in order to foster a better demeanor and improve rapport with prisoners, working and living conditions for the guards had to be ameliorated. It was in this vein that an investigatory commission convened by the governor of New Caledonia to examine the corps of wardens in the wake of the Communard scandal concluded that although some guards performed their jobs well and ethically, others failed out of weakness or exhaustion. «Many, discouraged by the fatigue of service or lack of compensation, serve without vigor or display a real cruelty toward the condamné. Thus, what do we see daily? Regrettable scenes of disorder, indiscipline, and violence» ${ }^{54}$.

Indeed, a number of factors continued to inhibit the development of morale and performance and militated against establishing a professional self-image in the corps. First, the perquisites established in the decree of 1867 did not suffice to meet the exigencies of life in the penal colonies. In Guyana, where the specter of illness and 
death was ever-present, officials urged the administration to provide «medical care for guards and their dependents» ${ }^{55}$.

As no hospital care was provided to guards or their families free of charge, many had to seek monetary assistance from penal colony authorities. Local officials were inundated with written pleas from guards desperate to make ends meet. In one case, a warden second class wrote: «Since I have been in the hospital my wife and child have not had the five francs a day that I would normally earn. On my salary my means are very restricted, and now without it and with the great costs of hospitalization, my family is in a state of penury. I would like to obtain a reduction in these costs, which would be of great help to me and my family» ${ }^{56}$.

41 It was not only the guard but his family that was exposed to tropical disease. A warden third class by the name of Fouque sought «an exoneration of the costs of hospitalization incurred by myself and my family from January 1 to the current day». Poignant evidence of his plight can be found in the list he attached to his letter, which detailed the number of visits he and members of his family made to the hospital to receive treatment for malaria.

\begin{tabular}{|l|l|}
\hline Son & 14 years old. Entered January 2 left January 6 \\
\hline \hline Daughter & 10 years old. Entered January 2 left January 4 \\
\hline \hline Wife & Entered January 1 left January 6 \\
\hline Wife & Entered January 23 left January 27 \\
\hline Myself & Entered March 7 left March 13 \\
\hline Son & Entered March 16 left April 2 \\
\hline Daughter & Entered March 16 left April 2 \\
\hline Wife & Entered March 16 left April 3 \\
\hline Myself & Entered March 24 left April 7 \\
\hline \hline Wife & Entered April 9 left April 14 \\
\hline Son & Entered April 9 left April 14 \\
\hline Total & 89 days at 2.40 per day $=213.60$ francs ${ }^{57}$ \\
\hline
\end{tabular}

Given that the salary for a warden third class was only 1,300 francs per year, this bill for treatment was no inconsiderable sum. Although requests for debt forgiveness were heard by the Ministry on a case-by-case basis -in this instance the amount to be repaid was lowered by 115 francs -the long-standing policy had been not to provide free hospital care to penal colony guards.

43 One also gains a sense of the precarious financial situation guards faced when examining the documents surrounding the admission of children into military 
boarding schools. Such schools were separate from those provided by the state in that they were free and available only to those had previously served in the military. For those guards who had not, however, tuition for room and board was charged. As such fees were typically beyond his means, the guard had to petition the administration for a waiver or reduction to gain admittance for his child. Aside from containing basic information (rank, location of posting, length of service, etc.), these records also include an assessment of the guard's general living situation as the administration had to make a determination based on financial need. Although this practice became something of a moot point with the increasing emphasis on prior military service in guard recruitment during the late nineteenth century, such records nevertheless provide a glimpse into the guard's family life.

What is apparent from these documents is that those with larger families had a distinct advantage in obtaining admittance for their child. Not coincidentally it was these same individuals who had the greatest pecuniary interest in having the child removed from the household and placed in the financial hands of the military. In this context we see Surveillant Third Class Rolland submit a request for his seven-year old son Adrien. The administration determined that Surveillant Rolland, the father of four other children, was «in a most precarious financial situation with needs and debts beyond his means». Given this determination, and with his record of good service, Adrien was admitted. In contrast, however, Surveillant Second Class Marty had only two children, and while he was also a «reliable server», with a "very dignified family», the administration decided that «his financial situation» did not merit such an action, although «it might demand more study in the future» (i.e. if there were additional children). As Surveillant Second Class Charpiat had but one child, and "has lived with relative ease on his salary», his request was denied ${ }^{58}$.

As with prison guards in the metropole, penal colony wardens were quartered in barracks on prison grounds. Those who were married, however, were required to live outside the prison with their families. These individuals were forced to maintain a separate household without salary compensation. In a report forwarded to the Ministry, the inspector general of Guyana remarked that «the married wardens third class live in the most absolute distress; all are for the most part lacking the necessary resources to live... Their salary is insufficient for their needs ${ }^{59}$. In a missive to the Ministry, an investigatory commission characterized the situation of a guard third class with a family as «without dignity... These unfortunates are obliged to live by shameful expedients. While the majority remain honest, others resort to illegal activities» ${ }^{60}$.

Official reports are replete with complaints against wardens «who, because of their economic situation, permit their wives to sell themselves, which is the cause of even more scandalous behavior and grave disorder... The husbands who engage in such a commerce are as guilty as the wives, and we should redouble are efforts to discover these agents, who merit severe punishment from their superiors ${ }^{61}$. Indeed, concern with the continued impropriety of the guards led officials to recognize «that although the Ministerial Decree of 1867 contained many excellent dispositions... its application was deficient ${ }^{62}$. Recognizing this, authorities attempted to rehabilitate the guard in the same manner as the convict. In 1881 the Ministry decreed that all married wardens were to be provided lodging (that is, a private home) adjacent to land suitable for a garden. In addition, each guard with three or more children was entitled to a supplementary ration, excluding wine and tafia. Finally, the decree established free 
medical care for the guard and his family. Such an effort would encourage the settlement of «honest and courageous families» in the penal colonies.

Although the decree of 1881 was intended, at least in part, to improve the standard of living for married guards, complaints persisted. Five years later, for instance, the director of the penal administration in Guyana observed that newly arrived guards could find no acceptable housing for their families; the administration had done too little to install or locate affordable living accommodations. If the government wished these noncommissioned officers to display goodwill and devotion to a difficult job, he noted, «it must provide them with a decent standard of living» ${ }^{63}$.

\section{Breakdown}

Although inadequate housing was a significant problem for penal colony personnel, abuse of alcohol was perhaps the greatest impediment to professionalism and posed the most serious threat to security in the bagnes. Indeed, drinking seemed to be the besetting sin of the warden and the means by which he staved off the isolation and boredom of life in the penal colonies. Disciplinary reports are testament to the pervasive and pernicious hold that alcohol had upon not only the life of the warden, but upon the daily operation of the penal colony itself. A physician in Guyana noted the sad case of Warden First Class Octeau who was admitted to the hospital in St. Laurent after «falling off his horse dead-drunk! (his emphasis)». Indeed, after a period of nearly fifteen hours in the hospital the guard was still inebriated. In his report to the administration, the physician mentioned that he had seen Octeau three times in a twomonth period for such behavior, and believed it «his duty to make it known that this agent should not be allowed to carry a weapon» as he posed a «real danger to public security» ${ }^{64}$. In his remarks to the Ministry, the governor of Guyana agreed that Octeau was a «habitual drunk», who had continued to drink to excess despite the «strongest admonitions of his superiors». Indeed, Octeau had served 128 days in jail since April 1904, and spent 24 days consigned to his room for five other occasions of drunkenness. Despite such a desultory record of behavior, however, the governor - in consultation with the penal colony administration - simply demoted Octeau to the second class ${ }^{65}$.

Such behavior and relatively minor disciplinary sanctions were not rare, nor limited to those guards serving in Guyana. In an examination of hundreds of individual dossiers one uncovers many incidents not unlike that involving the Warden Second Class Reydellet and Warden Third Class Rully, who, after an extended and very public drinking binge on the Isle des Pins in 1895, passed out. Upon awakening, Rully believed Reydellet to be dead, and frantically informed the commandant of the camp, who, along with the chef de médecin, found the latter to be in various states of undress and gesticulating wildly amid a large group of convicts. In the investigation that followed, it was noted that these men "always appear to be in a constant state of drunkenness», and that «the convicts in their care are often subject to brutalities while they were in this scandalous state».For their actions, both men were demoted to third class ${ }^{66}$.

In examining Reydellet's personnel file one finds a desultory career path that was all too typical. A thirty-eight year old single man from Lyon, Joseph Marius Reydellet had an unremarkable stint in the Navy as an NCO before heading to Guyana where he served for over ten years prior to his demotion in 1896. As we have already seen, advancement in rank was always difficult for penal colony guards, but Reydellet's 
record reflects an individual unconcerned by such matters, despite the fact that in his long tenure he had been promoted only once. In the year preceding his public drunkenness, the surveillant chef remarked that Reydellet «is a very ordinary server inclined to intemperance». The local commandant was harsher and more personal in his assessment of the guard, declaring «the subject [to be] a backbiter who disparages others». Reydellet finished his four-year term of service as a third class warden and returned to France in 1897.

51 Jean-Marie Rully followed a similar path in that he had served in the military, albeit as an artillery $\mathrm{NCO}$, before joining the penal colony corps and being shipped to New Caledonia. A thirty-six year old single man from the Isère, Rully had been promoted to second class in 1891. Interestingly, however, his file reflects a relatively reliable and dignified service in the colony, as his conduct and even his «morality» was always rated as «good» by his commandant. Nearly a year after his demotion, however, Rully was found dead of natural causes on June 21, 1897, although it was reported that he had been extremely drunk the preceding evening ${ }^{67}$.

Alcohol was also utilized as a justification or in defense of homosexual unions. One such case involved Wardens Third Class Ferdinand Rouge and Émile Vidal who were surprised while in bed by their comrades "committing an act of pederasty». In a report on the affair, both explained their actions as the result of their mutual drunkenness, and offered to be «demoted as recognition for the indignity they have brought to the uniform of all military wardens». Instead, the camp commandant immediately placed both guards in the prison on the Isle of Nou. Although he admitted that Wardens Rouge and Vidal «are just two of what seems to be an entire corps of inveterate drunks... we cannot lose consideration and all dignity. The presence of such individuals in the colony should no longer be tolerated $\aleph^{68}$. Both men had their commissions revoked and were returned to France.

Authorities were incapable, despite the pernicious and pervasive nature of alcoholism, of devoting anything more than lip service to the problem. In this regard, remarks such as those offered by General Borgnis-Desbordes in his investigation of the New Caledonian penal colony were typical: «... the corps is filled with incorrigible drunkards... the Inspector General has recommended that the chief wardens and principal wardens act with much greater rigor vis-à-vis drunkenness... Not a single drunk should remain in the corps of surveillants $»^{69}$. Aside from trying individual wardens before disciplinary panels when determining punishments for such behavior typically time served in a civil prison, or for repeat offenses, revocation from the corps - no coherent policy initiative about alcohol was ever enacted by penal colony authorities.

There was also longstanding discontent over the fact that after the first wave of appointments following the militarization of the corps in 1867, the rate of promotion once again began to stagnate. As early as 1872 , a governor's commission noted that «experience demonstrates that advancement is still not very rapid, which discourages and impairs the spirit of guards who dream of a better future. They are often tempted to resign, even though they have not yet finished their service, and this idea, even when they do not act upon it, adversely affects their zealousness and conduct» ${ }^{70}$. Indeed, a quarter of all the wardens third class in Guyana, none were advanced during a period of nearly five years between $1890-1895$, and more than half of the twenty-seven 
men promoted to second class had languished in the third-class rank for five or six years ${ }^{71}$.

Perhaps the greatest barrier to the development of a professional self-image among penal colony wardens was their pay. Indeed the pay scale established by the decree of 1867 -while generous in comparison to what the metropolitan prison guard received was still lower than that provided by the military.

Principal guard $-4,500$ vs. Warden principal $-4,000$

Guard 1 st class $-3,850$ vs. Warden Chief 1 st class $-3,500$

Guard 2nd class $-3,400$ vs. Warden Chief 2nd class 3,000

Cavalry sergeant $-2,502$ vs. Warden 1 st class $-2,400$

Infantry officer $-2,202$ vs. Warden 2 nd class $-2,000$

Non-commissioned officer $-2,002$ vs. Warden 3 rd class- $1,600^{72}$

Thus, the recruitment of guards was poor. In many minds, the penal colony guard ranked no higher than a common soldier in terms of social status. Certainly, a warden's pay was no better, as Inspector General Bourget remarked: «During the course of my inspection of surveillants, I have noticed that guards earn less than non-commissioned officers in the army. This situation is to the disadvantage of the service... If this is not ameliorated, recruitment to the corps of surveillants will remain difficult, if not unrealizable» ${ }^{73}$. The governor of Guyana also observed that recruitment was difficult and good applicants rare. "At the beginning", he added, "some non-commissioned officers of good caliber, lured by the prospect of rank, entered the corps of surveillants, but today the non-commissioned officers of the army are sufficiently recompensed, while our situation of employment is difficult and insufficiently remunerated ${ }^{74}$.

The situation was no better in New Caledonia, where recruitment remained difficult and turnover quite high. An 1881 inspection report acknowledged that the corps in New Caledonia was insufficient in all aspects. In that year, the number of guards was 305 and dropping, while the number of convicts was 3,500 and rising ${ }^{75}$. The situation in Guyana was nearly the same as the governor noted in a report to the Ministry that there were only 75 guards for the nearly 1,300 convicts in the colony, and only 32 for the 1,000 convicts on the Iles du Salut, neither of which met the four percent guard-toprisoner ratio established with the 1867 decree $^{76}$.

Given their limited number, exacting conditions, and potentially precarious circumstances, it is not surprising that the violence against prisoners continued. In one of many reports, an inspector noted that: «It is clear that grave acts of brutality are still being committed by surveillant militaires on condamnés... Following an investigation, I do not hesitate to ask of the Ministry to make a severe example of those who continue to act in this manner ${ }^{77}$ ». Governor Rodier of Guyana characterized guards as having «no ability to reason or ability to convey any sense of moral persuasion, they are too often are carried to exert strong force, which leads to abusive punishments». He spoke of seeing "condamnés, who are not bad workers, punished to days and sometimes months in the cachot for chattering or having smoke while at work. And for smoking what? The butts of cigarettes thrown to the ground by surveillants ${ }^{78}$ ».

No program of practical training for guards was ever put into place by penal colony authorities that might have established a better sense of decorum toward the prisoner, despite the fact there was a special school for the training of guards in metropolitan jails that operated between $1893-1934^{79}$. There was some discussion in the early 1930 s among some officials about the possibility of some sort of extended cours in which 
guards would be taught on general rules of comportment and elemental penal and juridical codes pertaining to transportation and the rights of prisoners. Indeed, it was noted in a report on the subject that «most young surveillants do not appear to be instructed in the tasks which they are to accomplish. I fear that they are even ignorant, for the most part, of the fundamental regulations of transportation and relegation». However, no definitive action was ever taken in this regard, and the training of guards remained the province of individual camp commandants, which meant, for all practical purposes, that it was non-existent ${ }^{80}$.

61 The damage seemed irrevocable as one local inspector to concluded rather ominously: «For many, many years the number of guards has been insufficient, as evident in the yearly reports, which have never ceased to express to the Ministry this shortage of personnel and how this is connected to their often dire circumstances... As the number of agents continues to diminish, those who remain are increasingly overworked and overburdened. In these conditions, the progress of the service has never been and will never be assured $\aleph^{81}$.

\section{Conclusion}

62 Were the guards aberrant personality types, predisposed to brutality? In his study of Police Battalion 101, Christopher Browning cites a Stanford University prison experiment in which a «normal»-based upon earlier psychological profiling - test group assumed roles as guards and prisoners in a simulated prison. While corporal punishment was obviously not available as a means of coercion for the test subjects, it was discovered that «within six days the inherent structure of prison life - in which guards operating on three-man shifts had to devise ways of controlling the more numerous prisoner population-had produced rapidly escalating brutality, humiliation, and dehumanization. It was the "prison situation», and not the individual personality, which produced «the anti-social behavior»" ${ }^{82}$.

63 This is particularly relevant in understanding the behavior of the penal colony corps. With fewer and fewer recruits, and the extreme nature of life in the penal colonies with its isolation, material deprivations, and endemic disease - it is not surprising that guards continued to employ violence and abused disciplinary practices such as cellular isolation well after such punishments were banned following the Communard scandal. The increasing demands placed upon the corps and the changing nature of thepenal colonies facilitated such behavior. This resulted in accusations of failure from those inside and outside the institution.

Despite the fact the guard was the pillar upon which the disciplinary edifice of the penal colonies rested, their low morale and indiscipline clearly impinged upon the institutional regime itself. The attempt by administrators to militarize the penal colony corps in 1867 -which, one could conceivably argue, established and fostered an environment in which the abuse of prisoners was tacitly tolerated -was continually undermined by the refusal of the Ministry to adequately address the significant problems facing guards everyday such as low pay and a stagnant career structure; both of which inhibited the development of any sense of professionalism among the rank and file. Thus, the warden would act as neither soldier nor bureaucrat, but instead remain the simple turnkey so loathed by administrators and Ministerial officials at the onset of transportation in 1854. 


\section{BIBLIOGRAPHY}

Bentham, J. The Works of Jeremy Bentham, ed. J. Bowring, 11 vols., Edinburgh, William Tart, 1843.

Bamford, P., Fighting Ships and Prisons: The Mediterranean Galleys of France in the Age of Louis XIV, Minneapolis, University of Minnesota Press, 1973.

Bourdet-Pléville, M., Justice in Chains: From the Galleys to Devil's Island, trans. Anthony Rippon, London, Robert Hale, 1960.

Browning, C., Ordinary Men: Reserve Police Battalion 101 and the Final Solution in Poland, New York, Harper, 1992.

Bullard, A., Exile to Paradise: Savagery and Civilization in Paris and the South Pacific, 1790-1900, Stanford, Stanford University Press, 2000.

Carlier, C., (ed.), Le personnel des prisons françaises au XIXe siècle, Paris, ministère de la Justice, 1987. Foucault, M., Discipline and Punish: The Birth of the Prison, trans. Alan Sheridan, New York, Vintage Books, 1977.

Haney, G., Banks, C., Zimbardo, Ph., «Interpersonal Dynamics in a Simulated Prison», International Journal of Criminology and Penology 1, 1983, pp. 69-97.

Hume, L.J., «Bentham's Panopticon: An Administrative History», Historical Studies, 15 1973, pp. 703-721; 16, 1974, pp. 36-54.

Laurent, É., Les châtiments corporels, Lyon, Librairie Phily, 1912.

Le Clère, M., Histoire de la police, Paris, Presses universitaires de France, 1964.

Le Clère, M., La Vie quotidienne dans les bagnes, Paris, Hachette, 1973.

Levi, P., The Drowned and the Saved, New York, Viking, 1989.

Mayer, S., Souvenir d'un déporté: Étape d'un forçat politique, Le Petit National, November 4, 1879.

Miles, A., Devil's Island, Berkeley, Ten Speed Press, 1982.

O’Brien, P., The Promise of Punishment, Princeton, Princeton University Press, 1982.

Payne, H.C., The Police Sate of Louis Napoléon Bonaparte, 1851-1860, Seattle, University of Washington Press, 1964.

Pierre, M., La Terre de la grande punition, Paris, Ramsay, 1982.

Petit, J.-G., (ed.), LaPrison, le bagne et l'histoire, Geneva/Paris, Médecine et hygiène/Librairie des méridiens, 1984.

Petit, J.-G., et al., Histoire des galères, bagnes et prisons, XVIII ${ }^{e}-X X^{e}$ siècles: Introduction à l'histoire pénale de la France, Toulouse, Éditions privat, 1990.

Pierre, M., Le dernier exil: histoire des bagnes et des forçats, Paris, Gallimard, 1989.

Pisier, G., Les déportés de la commune et l'île des Pins, Paris, Musée de l'homme, 1971.

Redfield, P., Space in the Tropics: Developing French Guiana from Penal Colony to Launch Site, Berkeley, University of California Press, 2000.

Rivière, A., La colonisation pénale, Bulletin société générale des prisons, 1985 (January), pp. 380-381. 
Schnapper, B., Le remplacement militaire en France: quelques aspects politiques, économiques et sociaux du recrutement au XIX $X^{e}$ siècle, Paris, SEVPEN, 1968.

Un vieux colonial [pseud.], La Colonisation et le bagne à la Nouvelle-Calédonie, Périgueux, Imprimerie Cassard Jeune, 1902.

Wright, G., Between the Guillotine and Liberty: Two Centuries of the Crime Problem in France, Oxford, Oxford University Press, 1983.

Zinoman, P. The Colonial Bastille: A History of Imprisonment in Vietnam, 1862-1940, Berkeley, University of California Press, 2001.

Zysberg, A., Galley Rowers in the Mid-Eighteenth Century, in Forster R., Ranum O. (eds.), Deviants and the Abandoned in French Society: selections from the Annales, économies, sociétés, civilisations (vol. IV), Baltimore, John Hopkins Press, 1973.

\section{NOTES}

2. For information on the distinction between deportation and transportation see O'Brien (1982, p. 260).

3. O'Brien has estimated that of the $« 29,000$ prisoners shipped to Guyana and New Caledonia between 1852 and 1875, 11,267 died, almost all from sickness and disease. Between 1871 and 1885, 42,000 prisoners were shipped to the two penal colonies. Of that number, 16,440 had died from sickness by 1885». O’Brien (1982, pp. 269-270).

4. Most prisoners in early modern France served as oarsmen in the galleys, which - given the brutal conditions aboard these vessels - was akin to a death sentence. Advances in design that allowed for more efficient sailing, however, made the ships and the convicts necessary for their propulsion obsolete, and the management and maintenance of the convicts who endured years of arduous rowing, was turned over to the Ministry of the Marine. For information on the galleys, see Zysberg (pp. 83-110); Bamford (1973); Bourdet-Pléville (1960).

5. Bulletin des lois, 178 (1854): 1439-1442.

6. For perspective on the panopticon see: Foucault (1977); Hume (1973, pp. 703-721); (1974, pp. 36-54). See also Bentham, ed. Bowring (11 vols., 1843).

7. Levi (1989, p. 36).

8. In this regard, see: Miles (1982); Pierre (1982); Le Clère, (1973). For accounts within the context of crime and punishment in France, see Wright (1983); Petit (1984); Petit et al. (1990).

9. Redfield (2000).

10. Bullard (2000).

11. In regard to the overseas bagnes Foucault had little to say, other than referring to transportation and deportation as a «rigorous and distant form of imprisonment». He also noted that it did little for the colonial enterprise and was of no real economic importance in either New Caledonia or Guyana. See Foucault (1977, pp. 272, 279).

12. Zinoman (2001, p.7).

13. Inspection rapport. November 3, 1865, p. 6. Carton H24. Centre des Archives d'Outre-Mer, Aix-en-Provence. Hereinafter AOM.

14. Letter from Inspector General Napoigne to the Ministry of the Marine. September 10, 1867, p. 1. Carton H1257, AOM.

15. Rapport du Contre-Amiral Gicquel de Tauche, directeur du personnel to the Ministry of the Marine. October 24, 1867. Carton H1257, AOM.

16. Letter from Governor Guillain of New Caledonia to the Ministry of the Marine. June 1, 1867. Carton H1257, AOM. 
17. Report from the governor of Guyana to the Ministry of the Marine. November 29, 1861. Carton H1257, AOM.

18. Letter from Governor Guillain of New Caledonia to the Ministry of the Marine.

19. Letter from the governor of Guyana to the Admiral Minister of the Marine. February 11, 1870. Carton H1258, AOM.

20. Letter from the governor of Guyana to the Ministry of the Marine. May 15, 1858. Carton H1257. AOM.

21. Projet d'organisation pour un corps militaire destiné à remplacer celui des surveillants dans le service pénitentiaire de la Guyane (Cayenne: Imprimerie du gouvernement, 1856), 1-2.

22. Bernard Schnapper has calculated that while there were 354,000 men in the army in January 1852, there were 526,000 in January 1856; Schnapper (1968, pp. 293, 271).

23. Payne (1964, p. 235).

24. Le Clère (1964, p. 85).

25. Rapport du Contre-Amiral Gicquel de Tauche, directeur du personnel to the Ministry of the Marine.

26. Report from the governor of Guyana to the Ministry of the Marine.

27. Note from Captain de Vaisseau, director of personnel to the Ministry of the Marine. March 28, 1867. Carton H1234, AOM.

28. Rapport du Contre-Amiral Gicquel de Tauche, directeur du personnel to the Ministry of the Marine.

29. Report from the governor of Guyana to the Ministry of the Marine.

30. Note relative à l'organisation administrative et financière du service de la transportation à la Guyane. July 29, 1868. Carton H10, AOM.

31. Instruction professionnelle. Carton H1258, AOM.

32. Ibid.

33. Rapport du Contre-Amiral Gicquel de Tauche, directeur du personnel to the Ministry of the Marine.

34. Ibid.

35. Carlier (1987, p. 38).

36. Notes du surveillant Heiss relatives au corps militaire des surveillants dans les colonies pénitentiaires. August 27, 1875. Carton H1257, AOM.

37. Rapport du gouverneur Guillain. July 25, 1869. Carton H24, AOM.

38. Rapport du gouverneur de la Richerie. May 5, 1871, 2-3. Carton H24, AOM.

39. Rapport du gouverneur Guillain. Third trimestre, 1870. Carton H24, AOM.

40. Letter to the Ministry of the Marine from the inspector general of New Caledonia. July 11, 1873. Carton H1861, AOM.

41. Notes du Surveillant Heiss relative au corps militaire des surveillants dans les colonies pénitentiaires.

42. In 1880, the former Communards received an amnesty and were allowed to return to France. While the vast majority would return home, approximately 140 déportés would remain in New Caledonia. See Pisier (1971, n. 1, p. 43).

43. Mayer $(4,1879)$.

44. See Réveil Social, Le Citoyen, and Le Temps for the full extent of the press campaign from 1879-1880.

45. Bullard (2000, pp. 244-251).

46. Ministerial circular on the subject of penal colony wardens. April 10, 1886.

47. Decree Concerning the Disciplinary Regime in the Overseas Establishments of Hard Labor. Number 9570, June 18, 1880. Carton H2028, AOM.

48. Report to the Governor of Guyana from the Director of the Penitentiary Administration. January 26, 1888. Carton H1222, AOM. 
49. Ibid.

50. Un vieux colonial [pseud.] (1902, p. 138).

51. Unsigned report on the functioning of guards in New Caledonia. April 19, 1881. Carton H1258, AOM.

52. Rivière (1885, pp. 380-381).

53. Laurent (1912, pp. 219-222).

54. Report of the commission named by decision of the governor to examine the actual situation of the corps of surveillants and to propose a project for reorganization. 1881. Carton H1258, AOM. 55. Report of April 15, 1881. Carton H1258, AOM.

56. Letter from Warden Second Class Lachèze to the director of the penitentiary administration. July 13, 1880. Carton H1212, AOM.

57. Letter from Warden Third Class Fouque to the director of the penitentiary administration. April 14, 1881. Carton H1258, AOM.

58. Tableaux de présentation pour les places d'enfants de troupe. New Caledonia. 1876. Carton H1234, AOM.

59. Inspection General of Guyana. 1885. Carton H1215, AOM.

60. Report presented by the commission named by the decision of the governor to examine the actual situation of the corps of surveillants and to propose a project for reorganization.

61. Report on the service of transportation. 1873. Carton H1861, AOM.

62. Report presented by the commission named by decision of governor to examine the actual situation of the corps of surveillants and to propose a project for reorganization.

63. Dépêche from the Director of the Penitentiary Administration in Guyana to the Ministry of the Marine. Observations relatives à l'installation matérielle des surveillants. July 13, 1886 . Carton H1861, AOM.

64. Letter from Dr. Grandmarie to the commandant of the penitentiary at St. Laurent with regard to Gustave Octeau, surveillant second class. No date. Carton H1246, AOM.

65. Letter from the governor of Guyana to the Minister of the colonies with regard to Gustave Octeau, surveillant second class. September 28, 1905. Carton H1246, AOM.

66. Report to the minister of the colonies on the demotion of Surveillants Reydellet and Rully. February 7, 1896. Carton H1246, AOM.

67. Inspection générale de 1897. Registre des notes confidentielles. Carton H5187. AOM.

68. Note given to the governor of Guyana from the penitentiary administration. May 28, 1905. Carton H1234, AOM.

69. Borgnis-Desbordes, Report on Transportation and Relegation, 1888. Carton H1214, AOM.

70. Letter from Inspector Leboul to the Ministry of the Marine. September 25, 1872. Carton H1258, AOM.

71. Letter from Governor Moutet of Guyana to the Minister of the Colonies. October 16, 1899. Carton H1216, AOM.

72. Inspection General of 1878. Reorganization of corps of surveillants. Modifications proposed to decree of 1867. Carton H1258, AOM.

73. Letter from Inspector General Bourget to the Ministry of the Marine. October 17, 1888. Carton H1215, AOM.

74. Letter from the governor of Guyana to the Ministry of the Marine. December 15, 1885. Carton H1215, AOM.

75. Report presented by the Commission named by Decision of Governor to examine the actual situation of the corps of surveillants and to propose a project for reorganization.

76. Letter from the governor of Guyana to the Minister of the Colonies. December 13, 1894. Carton H1234, AOM.

77. Report to the minister of the colonies from the director of the penitentiary administration. June 1, 1897. Carton H1246, AOM. 
78. Confidential letter from Governor Rodier of Guyana to the minister of the colonies. December 31, 1907. Carton H1862, AOM.

79. O'Brien (1982, p. 222).

80. Letter from the minister of the colonies to the governor of Guyana. November 24, 1932. Instruction professionnelle des surveillants militaires. Carton H5189, AOM.

81. Notice sur le fonctionnement des services pénitentiaires pendant l'année 1926. Carton H1928, AOM.

82. Haney (1983, pp. 69-97). Cited in Browning (1992, pp. 167-168).

\section{ABSTRACTS}

Du fait de leur situation isolée et de l'éloignement de la France, les gardiens des bagnes de Nouvelle-Calédonie et de Guyane contrôlaient directement et totalement la vie en détention. Ils frappaient et torturaient couramment les bagnards et il leur arrivait d'exécuter publiquement ceux qui commettaient des infractions ou violaient la discipline de l'établissement. N'étaient-ils que des sadiques, des instruments consultants de la violence d'État? Cet article examine la vie et la culture institutionnelles des gardiens de bagne afin de répondre à ces questions. En dépit d'une théorique militariste destinée à conforter la discipline et la surveillance des bagnes et une organisation conçue pour susciter fierté et sens du devoir, les gardiens étaient, tout comme les détenus, au banc de la société: c'était un groupe plus ou moins rejeté par ses pairs. La mise en place d'un ensemble complexe de procédures et de directives, ainsi qu'un système de nominations, de gratifications et de promotions n'a pas suffi à donner à ce corps l'apparence d'une formation militaire professionnelle. En effet, une série d'obstacles - aussi bien structurels qu'individuels - l'ont empêché de constituer un appareil disciplinaire efficace. Les gardiens vivaient dans une sorte d'entredeux professionnel, ni militaire, ni bureaucrate, mais simple geôlier méprisé autant par les administrateurs que par les détenus.

Given their remote location and great distance from France, guards in the penal colonies of New Caledonia and Guyana had immediate and total control over prison life. As such, they routinely engaged in the beating and torture of the bagnards, and even carried out public executions for those guilty of legal and disciplinary infractions while in their charge. Were these men simply sadistic brutes, willing instruments of state-sanctioned violence? This article examines the institutional life and culture of the penal colony guard in an attempt to answer this question. Despite rhetoric that emphasized militarism as a means to assure discipline and surveillance in the penal colonies, and a professional structure designed to fashion and instill a sense of pride and purpose, the guards, like the prisoners, were beyond the pale; a group somehow rejected by their peers. Even with the establishment of a complex set of procedures, guidelines, and a system of appointments, perquisites, and promotions, the corps never took on the air of a professional military service as a variety of obstacles - structural and individual -impeded its development as an effective disciplinary apparatus of the bagnes. The guard lived in an occupational netherworld in which he was neither soldier nor bureaucrat, but a turnkey loathed by administrators and prisoners alike. 


\section{AUTHOR}

\section{STEPHEN A. TOTH}

College of Arts and Sciences, Arizona State University, $4701 \mathrm{~W}$. Thunderbird Rd, Glendale, AZ 85306-4908, USA, stoth@asu.edu

Stephen A. Toth is an Assistant Professor of History at Arizona State University West. His work on crime and the French colonial world has appeared in numerous scholarly journals, and is currently revising a book-length manuscript for publication entitled Neither Myth nor Monolith: A History of the French Overseas Penal Colonies, 1854-1952. 